\title{
ANALISIS GEMPA NON-LINEAR STATIC PUSHOVER DENGAN METODE ATC-40 UNTUK EVALUASI KINERJA STRUKTUR BANGUNAN GEDUNG
}

\author{
Hilda Pradita Suwandi \\ 1) Fakultas Teknik, Program Studi Teknik Sipil, Universitas Veteran Bangun Nusantara, Sukoharjo, J1. \\ Letjen Sudjono Humardhani, No.1, Jombor, Sukoharjo; Telp. 0271-593156. \\ Email: praditahilda88@gmail.com
}

\begin{abstract}
Abstrak
Indonesia merupakan negara yang berada di wilayah rawan gempa. Bencana gempa merupakan gejala alam yang bersifat destruktif. Konsep dan metode baru dalam analisis dan perencanaan bangunan tahan gempa salah satunya konsep Performance Based Seismic Evaluation (PBSE) dengan metode analisis beban dorong statik atau analisis Pushover. Metode ini mampu memberikan informasi pola keruntuhan bangunan eksis ketika terbebani gaya gempa yang melebihi kapasitas bangunan, apakah terjadi keruntuhan langsung atau bangunan mampu berperilaku nonlinier (progresif) sebelum terjadi keruntuhan total. Tujuan penulisan tugas akhir ini adalah re-evaluasi kinerja tahanan gempa gedung Rumah Sakit untuk mengetahui kapasitas gempa efektif struktur dan perilakunya dengan memperlihatkan skema terjadinya sendi plastis pada elemen balok dan kolom dengan metode Pushover berdasarkan peraturan Code Applied Technology Council (ATC-40) serta menentukan level kinerja struktur terhadap tahan gempa berdasarkan code tersebut. Pertimbangan penulis memilih gedung Rumah Sakit sebagai obyek penelitian karena fungsi gedung bersifat massal sehingga didesain yang sesuai dengan kuat rencana. Dari hasil penelitian,didapat gaya geser dasar efektif 3563,668 ton lebih dari gaya geser dasar rencana 2648,7532 ton dengan percepatan puncak batuan dasar $0.012 \mathrm{~g}$ kurang dari percepatan puncak batuan dasar rencana wilayah gempa 3 yakni $0.15 \mathrm{~g}$. Struktur bangunan mampu memberikan perilaku nonlinier yang ditunjukkan fase awal dan mayoritas terjadinya sendi-sendi plastis terjadi pada elemen balok baru kemudian elemen kolom. Level kinerja struktur masuk kriteria Immediate Occupancy.
\end{abstract}

Kata kunci : Pushover, Nonlinier, Sendi plastis.

\begin{abstract}
Indonesia is a country located in earthquake-prone areas. Earthquake disaster is a destructive natural phenomenon. New concepts and methods in the analysis and planning of earthquake resistant buildings, one of which is the concept of Performance Based Seismic Evaluation (PBSE) with static thrust load analysis methods or Pushover analysis. This method is able to provide information on building collapse patterns that exist when overburdened by earthquake forces that exceed the capacity of the building, whether there is a direct collapse or the building is able to behave nonlinearly (progressively) before a total collapse occurs. The purpose of this thesis is to re-evaluate the performance of earthquake resistance in the Hospital building to determine the effective earthquake capacity of its structure and behavior by showing the scheme of the occurrence of plastic joints on beam and column elements by the Pushover method based on Code Applied Technology Council (ATC-40) regulations and determining level of structural performance against earthquake resistance based on the code. The authors' consideration of choosing the Hospital building as the object of research is because the function of the building is mass so that it is designed in accordance with the plan. From the results of the study, obtained an effective base shear force of 3563,668 tons more than the basic shear force of the plan of 2648.7532 tons with the acceleration of the bedrock peak of $0.012 \mathrm{~g}$ less than the acceleration of the bedrock peak of the earthquake zone plan 3 which is $0.15 \mathrm{~g}$. The structure of the building is able to provide nonlinear behavior which is indicated by the initial phase and the majority of plastic joints occur in the new beam element then the column element. The performance level of the structure is in the Immediate Occupancy criteria.
\end{abstract}

Keywords: Pushover, Nonlinear, Plastic joints.

\section{PENDAHULUAN}

Indonesia menempati zona tektonik yang sangat aktif karena tiga lempeng besar dunia dan sembilan lempeng kecil lainnya saling bertemu di wilayah indonesia dan membentuk jalur-jalur pertemuan lempeng yang kompleks, hal ini menyebabkan indonesia menjadi sangat rawan terhadap gempa bumi. Pada proses perancangan struktur bangunan berbeban gempa diperlukan standar dan peraturan perancangan bangunan 
untuk menjamin keselamatan penghuni terhadap gempa besar yang mungkin terjadi serta menghindari dan meminimalisir kerusakan struktur bangunan dan korban jiwa akibat gempa bumi.

Kecenderungan terbaru perencanaan bangunan tahan gempa saat ini adalah perencanaan berbasis kinerja (Performance Based Design / PBD). Konsep perencanaan berbasis kinerja merupakan kombinasi dari aspek ketahan dan aspek layan. Perencanaan tahan gempa berbasis kinerja (Performance - Based Seismic Design) sebagai pengembangan dari konsep PBD merupakan proses yang dapat digunakan untuk perencanaan bangunan baru maupun perkuatan (retrofit) bangunan yang sudah ada, dengan pemahaman yang realistik terhadap resiko keselamatan (life), kesiapan pakai (occupancy) dan kerugian harta benda (economic loss) yang mungkin terjadi akibat gempa yang akan datang (Pranata,2006).

Gempa merupakan salah satu penyebab terjadinya perubahan pembebanan pada struktur yang tidak dapat diramalkan kapan terjadinya. Dengan adanya pengaruh gaya lateral dari gempa yang terjadi dapat mengakibatkan penurunan kinerja pada struktur gedung. Penurunan kinerja dapat mengurangi tingkat keamanan dan umur struktur bangunan. Perlu dilakukan penilaian kecukupan kinerja dan keamanan struktur bangunan eksisting sebelum terjadinya bencana yang tidak diinginkan.

Pada saat ini dengan memanfaatkan teknik analisis non-liniear berbasis komputer yang biasa dikenal dengan NonLinear Static Pushover Analysis kita dapat mengetahui perilaku inelastis struktur sehingga dapat diketahui kinerjanya pada kondisi kritis. Evaluasi kinerja dengan NonLinear Static Pushover Analysis dilakukan dengan terlebih dahulu menentukan target peralihan. Beberapa kriteria yang dapat dilakukan dalam NonLinear Static Pushover Analysis diantaranya capacity spectrum (ATC-40), metode displacement coefficient (FEMA 356) dan metode displacement coefficient yang diperbaiki (FEMA 440).

\section{Analisis Pushover Statik Nonlinier}

Analisis statik nonlinier merupakan prosedur analisa untuk mengetahui perilaku keruntuhan suatu bangunan terhadap gempa, dikenal pula sebagai analisa Pushover atau analisa beban dorong statik.
Analisis dilakukan dengan memberikan beban lateral statik pada struktur, yang kemudian secara bertahap ditingkatkan dengan faktor pengali sampai satu target perpindahan lateral dari suatu titik acuan tercapai. Biasanya titik tersebut adalah titik pada atap, atau lebih tepat lagi adalah pusat massa atap.

Analisis pushover menghasilkan kurva pushover, kurva yang menggambarkan hubungan antara gaya geser dasar (V) versus perpindahan titik acuan pada atap (D). Pada proses pushover, struktur didorong sampai mengalami leleh disatu atau lebih lokasi di struktur tersebut. Kurva kapasitas akan memperlihatkan suatu kondisi linier sebelum mencapai kondisi leleh dan selanjutnya berperilaku nonlinier. Kurva pushover dipengaruhi oleh pola distribusi gaya lateral yang digunakan sebagai beban dorong.

Tujuan analisis pushover adalah mengevaluasi perilaku seismik struktur terhadap pembebanan gempa rencana berdasarkan kurva kapasitas yang terbentuk. Selain itu analisa ini juga dapat memberikan informasi bagian-bagian struktur mana saja yang kritis. Selanjutnya dapat diidentifikasi bagian - bagian yang memperlukan perhatian khusus untuk pendetailan atau stabilitasnya. Cukup banyak studi menunjukkan bahwa analisis statik pushover dapat memberikan hasil mencukupi, ketika dibandingkan dengan hasil analisis dinamik (Nonlinier) untuk bangunan reguler dan tidak tinggi (Dewobroto, 2005).

\section{Metode Capacity Spectrum ATC-40}

Capacity spectrum method menyajikan secara grafis dua buah grafik yang disebut spektrum, yaitu spektrum kapasitas (capacity spectrum) yang menggambarkan kapasitas struktur berupa hubungan gaya dorong total (base shear) dan perpindahan lateral struktur (biasanya ditetapkan di puncak bangunan), dan spektrum demand yang menggambarkan besarnya demand (tuntutankinerja)akibat gempa dengan periode ulang tertentu.

\section{Kurva Kapasitas}

Kurva kapasitas yang didapatkan dari analisis pushover menggambarkan kekuatan struktur yang besarnya sangat tergantung dari kemampuan momen-deformasi dari masing-masing komponen struktur. Cara termudah untuk membuat kurva ini adalah dengan mendorong struktur secara bertahap (pushover) dan mencatat hubungan 
antara gaya geser dasar (base shear) dan perpindahan atap akibat beban lateral yang dikerjakan pada struktur dengan pola pembebanan tertentu. Pola pembebanan umumnya berupa beban statik ekivalen, hal ini berlaku untuk bangunan yang memiliki periode fundamental struktur yang relatif kecil. Untuk bangunan yang lebih fleksibel dengan periode struktur yang lebih besar ,perencana sebaiknya memperhitungkan pengaruh ragam yang lebih tinggi dalam analisisnya. Hasil analisis statis pushover nonlinier adalah kurva yang menunjukkan hubungan antara gaya geser dasar (base shear) dan simpangan atap (roof displacement).

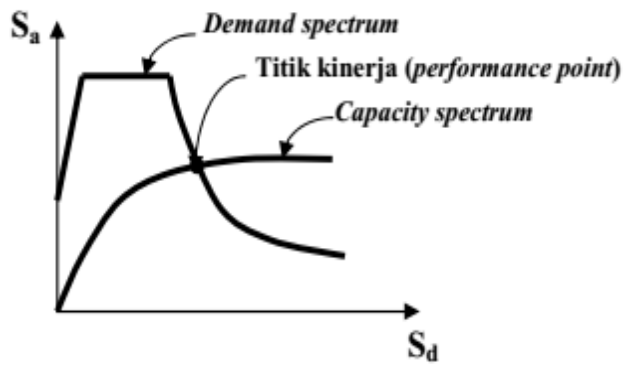

Gambar 1 Performance Point pada Capacity Spectrum Method

Sumber : Applied Technology Council, , Report ATC-40, (Redwood City : ATC,1996)
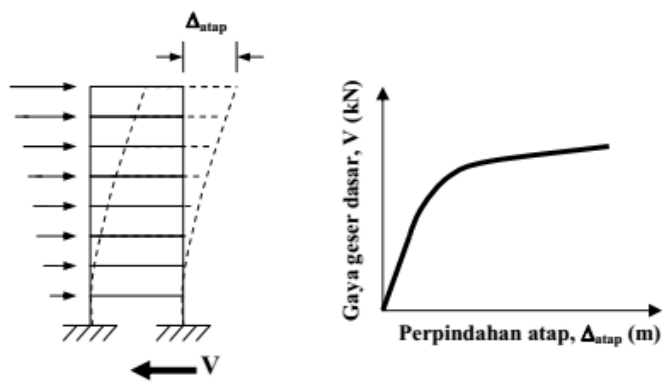

Gambar 2 Kurva Kapasitas

Sumber : Applied Technology Council, , Report ATC-40, (Redwood City : ATC,1996)

Hubungan tersebut kemudian dipetakan menjadi suatu kurva yang dinamakan kurva kapasitas struktur. Metode ini sederhana namun informasi yang dihasilkan sangat berguna karena mampu menggambarkan respon inelastic bangunan. Analisis ini memang bukan cara yang terbaik untuk mendapatkan jawaban terhadap masalah analisis dan desain, tetapi relative sederhana untuk mendapatkan respons nonlinier struktur.
Capacity curve hasil pushover diubah menjadi capacity spectrum seperti gambar 1 melalui persamaan 1 sampai 4 (ATC-40, 1996).

$S_{a}=$ $\frac{V / W}{\alpha_{1}}$

$S_{a}=$ $\frac{\Delta_{\text {atap }}}{P F_{1} \text { Iatap }_{1}}$

$P F_{1}=\left[\frac{\sum_{i=1}^{N}\left(w_{i} \emptyset_{i 1}\right) / g}{\sum_{i=1}^{N}\left(w_{i} \phi^{2}{ }_{i 1}\right) / g}\right]$

$\propto 1=\frac{\left[\sum_{i=1}^{N}\left(w_{i} \emptyset_{i 1}\right) / g\right]^{2}}{\left[\sum_{i=1}^{N}\left(w_{i} / g\right]\left[\Sigma_{i=1}^{N}\left(w_{i} \emptyset_{i 1}\right) / g\right]\right.}$

Dimana :

$\mathrm{Sa}=$ Spectral acceleration

$\mathrm{Sd} \quad=$ Spectral displacement

$\mathrm{PF}_{1}=$ modal participation untuk modal pertama

$\propto_{1} \quad=$ modal mass coefficient untuk modal pertama

$\emptyset_{i 1} \quad=$ amplitude of first untuk level $\mathrm{i}$

$\mathrm{V} \quad=$ gaya geser dasar

$\mathrm{W} \quad=$ berat mati bangunan di tambah beban hidup

$\Delta_{\text {roof }}=$ roof displacement

$\mathrm{wi} / \mathrm{g} \quad=$ massa pada level $\mathrm{i}$
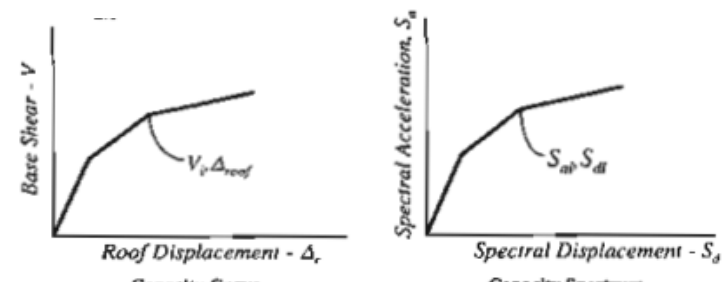

Gambar 3 Modifikiasi Capacity Curve menjadi Capacity Spectrum.

Sumber : Applied Technology Council, , Report ATC-40, (Redwood City : ATC,1996)

\section{Performance Point}

Performance point adalah titik dimana capacity curve berpotongan dengan response spectrum curve seperti yang dipergunakan dalam capacity spectrum method (ATC-40, 1996). Untuk memperoleh gambaran lebih jelas, dapat dilihat pada gambar 5. 
Pada performance point dapat diperoleh informasi mengenai periode bangunan dan redaman efektif akibat perubahan kekakuan struktur setelah terjadi sendi plastis. Berdasarkan informasi tersebut repons-respons struktur lainnya seperti nilai simpangan tingkat dan posisi sendi plastis dapat diketahui.

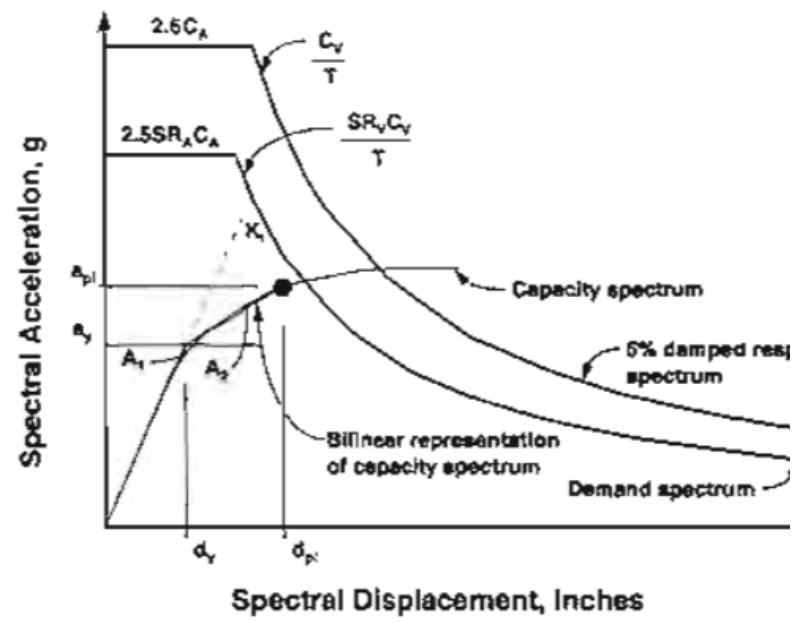

Gambar 4 Penentuan Performance Point Sumber : Applied Technology Council, , Report ATC-40, (Redwood City : ATC,1996)

Dalam penelitian ini dilakukan analisa tingkat kinerja dari bangunan RS. Indriyati Solo Baru yang akan dievaluasi terhadap peraturan terkait dengan metode ATC-40 dan pola keruntuhan gedung tersebut setelah dianalisis. Tujuan dilakukan penelitian ini adalah untuk mengetahui tingkat kinerja dari model bangunan RS. Indriyati Solo Baru yang dievaluasi terhadap peraturan terkait dengan metode ATC - 40 dan pola keruntuhan pada struktur bangunan tersebut.

\section{METODE}

\section{Metode penelitian}

Dari performance point hasil analisa pushover didapatkan nilai displacement efektif, gaya geser dasar, waktu getar efektif dan damping efektif. Dari nilai displacement akan diketahui kriteria kinerja seismik struktur berdasarkan ATC-40. Berdasarkan hasil analisis data dan pembahasan, maka dapat dibuat kesimpulan yang sesuai dengan tujuan penelitian. Tahapan penelitian ecara lengkap seperti Gambar 6, diagram alir penelitian.

\section{HASIL DAN PEMBAHASAN}

\section{a. Pembebanan Pada Gedung}

Beban Mati (Berat Sendiri) Bahan Bangunan dan Komponen Gedung

Beban mati yang akan dimasukkan dalam analisis SAP 2000 v14 terdiri dari dua beban, yaitu beban struktur disebut dengan dead load dan beban mati tambahan / beban komponen yang didefinisikan sebagai super dead load.

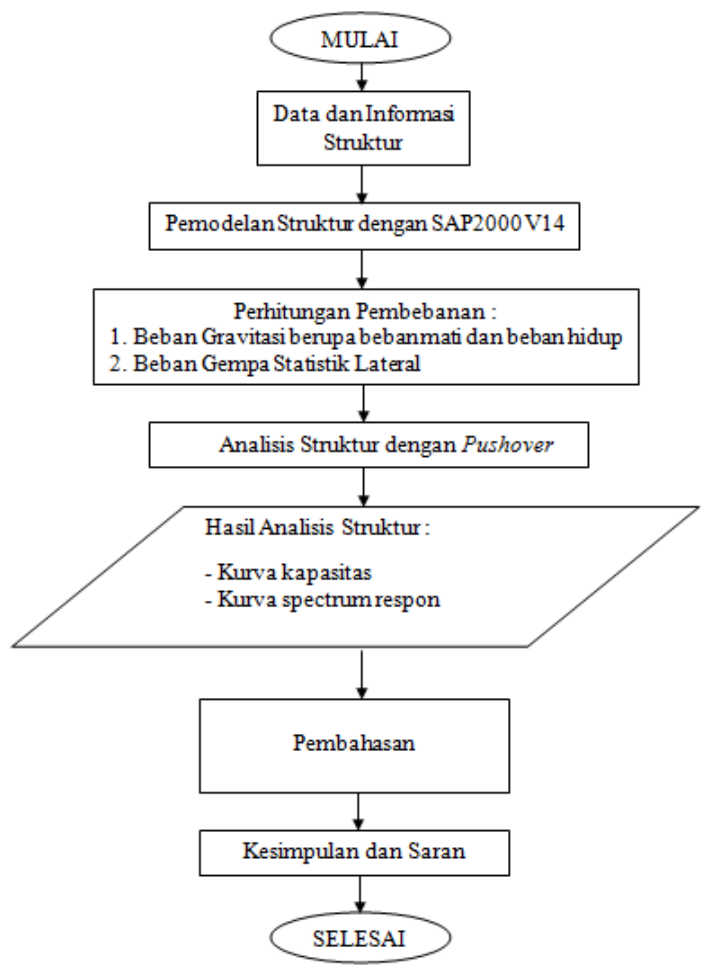

Gambar 5. Diagram alir penelitian

\section{Beban Hidup}

Beban hidup pada lantai gedung yang dimasukkan pada SAP 2000 V14 mengacu pada Standar Tata Cara Perencanaan untuk Rumah dan Gedung SNI 03-1727-1989, yaitu sebagai berikut :

Beban hidup atap (rumah sakit) $=100 \mathrm{~kg} / \mathrm{m}^{2}$

Beban hidup lantai (rumah sakit) $=250 \mathrm{~kg} / \mathrm{m}^{2}$

\section{Beban Total Struktur Gedung}

Beban total struktur gedung adalah penjumlahan dari beban gedung per lantai yang didapat dari beban mati, beban hidup, serta beban pada struktur tersebut.

\section{b. Analisis Beban Gempa}

\section{Perhitungan Periode Getar Pada Wilayah Gempa III (SNI 02-1726-2002)}

Taksiran waktu getar alami fundamental (T)

$\mathrm{T}$

$$
=\mathrm{C}_{\mathrm{t}} \cdot \mathrm{h}_{\mathrm{n}}{ }^{\beta}
$$

\section{Untuk}

$\mathrm{C}_{\mathrm{t}}=0,018$ (untuk sistem bangunan beton)

$\mathrm{H}_{\mathrm{n}}=82,5 \mathrm{~m}$ (tinggi sampai atap)

$\beta=0,90$ (untuk sistem bangunan beton)

Maka :

$$
\begin{aligned}
\mathrm{T} & =\mathrm{C}_{\mathrm{t}} \cdot \mathrm{h}_{\mathrm{n}}{ }^{\beta} \\
& =0,018 \times(82,05)^{0,90}
\end{aligned}
$$




$$
=0,95 \text { detik }
$$

Perhitungan Gaya Geser Nominal

$$
V=\frac{C . I}{R} x W t
$$

Untuk :

$\mathrm{V}=$ Gaya geser dasar nominal.

$\mathrm{C}=0,347$ (faktor respon gempa dari spektrum respons).

I $\quad=1,4$ (faktor keutamaan untuk bangunan rumah sakit).

$\mathrm{R}=6,5$ (faktor reduksi gempa representatif dari struktur gedung yang bersangkutan yang bersifat daktil penuh)

$\mathrm{Wt}=35440,296013$ ton (berat total gedung).

$$
\begin{aligned}
& \mathrm{V} \quad=\frac{\mathrm{C} . \mathrm{I}}{\mathrm{R}} \times \mathrm{Wt}= \\
& \begin{aligned}
\frac{0,347 \times 1,4}{6,5} & \times 35440296,013 \mathrm{~kg} \\
& =2648753,2 \mathrm{~kg} \\
& =2648,7532 \mathrm{ton} .
\end{aligned}
\end{aligned}
$$

Disribusi beban gempa statik ekuivalen

Rasio tinggi gedung dengan lebar ukuran gedung terbebani gempa :

$\mathrm{H} / \mathrm{Lx}=82,05 / 124,3$
$=0,66$

$\mathrm{H} / \mathrm{Ly}=82,05 / 107,752$

$$
=0,76
$$

$\mathrm{H} / \mathrm{Lx}<3$ dan $\mathrm{H} / \mathrm{Ly}<3$, maka beban geser dasar nominal $\mathrm{V}$, dibagi sepanjang tinggi struktur gedung, menjadi beban gempa nominal statik ekuivalen Fi yang mengangkap pada pusat massa lantai tingkat ke-i.

Perhitungan dilakukan sesuai dengan rumus SNI 03-1726-2002.

$$
F_{i}=\frac{W_{j} \cdot Z_{j}}{\sum_{i=1}^{n} W_{i} \cdot Z_{i}} V
$$

Dimana :

$\mathrm{Wi}=$ Berat lantai tingkat ke-i, termasuk babn hidup yang sesuai

$\mathrm{Zi}=$ Ketinggian lantai tingkat ke-i diukur dari taraf penjepitan lateral

$\mathrm{n}=$ Nomor lantai tingkat paling atas

$\mathrm{V}=$ Gaya geser dasar nominal

Kemudian didistribusi beban lateral tiap lantai disajikan dalam tabel 1 .

Tabel 1 Distribusi beban lateral tiap lantai.

\begin{tabular}{lcccc}
\multicolumn{1}{c}{ Lantai } & hi $(\mathbf{m})$ & Wi $(\mathbf{k g})$ & hi $\mathbf{~ W i ~}(\mathbf{k g m})$ & Fi $(\mathbf{k g})$ \\
\hline Lantai Atap & 82,05 & 181757,5 & 14913202,875 & 43790,451 \\
\hline Lantai Mesin & 80,05 & 1006068,94 & 80535818,647 & 236481,719 \\
\hline Lantai 19 & 75 & 1006068,94 & 75455170,5 & 221563,135 \\
\hline Lantai 18 & 71 & 1006068,94 & 71430894,74 & 209746,435 \\
\hline Lantai 17 & 67 & 1006068,94 & 67406618,98 & 197929,734 \\
\hline Lantai 16 & 63 & 955045 & 60167835 & 176674,098 \\
\hline Lantai 15 & 59 & 955045 & 56347655 & 165456,695 \\
\hline Lantai 14 & 55 & 955045 & 52527475 & 154239,291 \\
\hline Lantai 13 & 51 & 955045 & 48707295 & 143021,888 \\
\hline Lantai 12 & 47 & 955045 & 44887115 & 131804,485 \\
\hline Lantai 11 & 43 & 1036357 & 44563351 & 130853,8 \\
\hline Lantai 10 & 1036357 & 40417923 & 106508,353 \\
\hline Lantai 9 & 39 & 1036357 & 36272495 & 94336,46 \\
\hline Lantai 8 & 35 & 1036357 & 32127067 & 89128,107 \\
\hline Lantai 7 & 31 & 1036357 & 30353319 & 112828,105 \\
\hline Lantai 6 & 27 & 1036357 & 38424550,56 & 88015,752 \\
\hline Lantai 5 & 22 & 1036357 & 29974497,24 & 81908,043 \\
\hline Lantai 4 & 17 & 2145728 & 27894466,08 & 10082,534 \\
\hline Lantai 3 & 13 & 381521,2 & 3433690,8 & 5936,201 \\
\hline Lantai 2 & 9 & 404324,567 & 0 & 0 \\
\hline Lantai 1 & 5 & 670135,634 & & 2021622,835 \\
\hline
\end{tabular}

\section{Analisis Batas Layan Struktur Gedung}

Untuk memenuhi persyaratan kinerja batas layan struktur, dalam segala hal simpangan antar tingkat yang dihitung dari simpangan struktur gedung tidak boleh melampaui $\frac{0,03}{R} \mathrm{x}$ tinggi tingkat yang bersangkutan atau $30 \mathrm{~m}$, tergantung mana yang nilainya lebih kecil seperti persamaan dibawah ini :

$\Delta$ s antar tingkat $<\frac{0,03}{R} \times \mathrm{h}(\mathrm{SNI} 03-1726-2002)$

\section{Kinerja Batas Layan Arah X}

$\Delta \mathrm{s}$ antar tingkat

$\Delta$ s lantai Atap - lantai mesin $<\frac{0,03}{R} \times \mathrm{h}$

$0,101489-0,094418$ $<\frac{0,03}{R} x h$

$0,007071 \mathrm{~m}$ $<\frac{0,03}{6,5} \times 2$

$<0,00923 \mathrm{~m}$

(Memenuhi Syarat)

Untuk perhitungan kinerja batas layan arah X selanjutnya dapat ditampilkan pada tabel 3 . 
Jurnal Media Komunikasi Dunia Ilmu Sipil (MoDuluS)

Volume 1, No 1, Juni 2019

Tabel 3 Kinerja Batas Layan Struktur Gedung Arah X Lantai Tinggi (m)

Kinerja Batas Layan Arah X

$\Delta \mathrm{s}(\mathrm{m}) \quad \Delta \mathrm{s}$ antar tingkat $\quad$ Syarat $(\mathrm{m}) \quad$ Ket.

(m)

\begin{tabular}{lccccc}
\hline Lantai Atap & 2 & 0,101489 & 0,007071 & 0,009231 & OKE \\
\hline Lantai Mesin & 5,05 & 0,094418 & 0,009253 & 0,023308 & OKE \\
\hline Lantai 19 & 4 & 0,085165 & 0,007438 & 0,018462 & OKE \\
\hline Lantai 18 & 4 & 0,077727 & 0,006960 & 0,018462 & OKE \\
\hline Lantai 17 & 4 & 0,070767 & 0,006407 & 0,018462 & OKE \\
\hline Lantai 16 & 5 & 0,064360 & 0,005963 & 0,023077 & OKE \\
\hline Lantai 15 & 5 & 0,058397 & 0,005730 & 0,023077 & OKE \\
\hline Lantai 14 & 4 & 0,052667 & 0,005760 & 0,018462 & OKE \\
\hline Lantai 13 & 4 & 0,046907 & 0,005556 & 0,018462 & OKE \\
\hline Lantai 12 & 4 & 0,041351 & 0,005277 & 0,018462 & OKE \\
\hline Lantai 11 & 4 & 0,036074 & 0,005086 & 0,018462 & OKE \\
\hline Lantai 10 & 4 & 0,030988 & 0,005064 & 0,018462 & OKE \\
\hline Lantai 9 & 4 & 0,025924 & 0,004678 & 0,018462 & OKE \\
\hline Lantai 8 & 4 & 0,021246 & 0,004483 & 0,018462 & OKE \\
\hline Lantai 7 & 5 & 0,016763 & 0,004545 & 0,023077 & OKE \\
\hline Lantai 6 & 5 & 0,012218 & 0,003684 & 0,023077 & OKE \\
\hline Lantai 5 & 4 & 0,008534 & 0,002838 & 0,018462 & OKE \\
\hline Lantai 4 & 4 & 0,005696 & 0,002040 & 0,018462 & OKE \\
\hline Lantai 3 & 4 & 0,003656 & 0,001835 & 0,018462 & OKE \\
\hline Lantai 2 & 4 & 0,001821 & 0,00101 & 0,023077 & OKE \\
\hline Lantai 1 & 4 & 0,00072 & 0,00072 & 0,018462 & OKE \\
\hline TOTAL & 88,05 & & & & \\
\hline
\end{tabular}

\section{Kinerja Batas layan Arah Y}

$\Delta$ s antar tingkat $\quad<\frac{0,03}{R} \times h$
$\Delta$ s lantai Atap - lantai mesin $<\frac{0,03}{R} \times h$
$0,065865-0,062587$

$<\frac{0,03}{6,5} \times 2$

$0,003278 \mathrm{~m}<0,00923 \mathrm{~m}$ (Memenuhi Syarat) Untuk perhitungan kinerja batas layan arah $\mathrm{Y}$ selanjutnya ditampilkan pada tabel 4 .

Tabel 4 Kinerja Batas Layan Struktur Gedung Arah Y Lantai Tinggi $(\mathrm{m})$

Kinerja Batas Layan Arah Y

\begin{tabular}{lccccc} 
& & $\Delta \mathbf{s}(\mathbf{m})$ & $\Delta$ s antar tingkat $(\mathbf{m})$ & Syarat $(\mathbf{m})$ & Ket. \\
\hline Lantai Atap & 2 & 0,065865 & 0,0032780 & 0,009230769 & OKE \\
\hline Lantai Mesin & 5,05 & 0,062587 & 0,0080890 & 0,023076923 & OKE \\
\hline Lantai 19 & 4 & 0,054498 & 0,0053470 & 0,018461538 & OKE \\
\hline Lantai 18 & 4 & 0,049151 & 0,0052400 & 0,018461538 & OKE \\
\hline Lantai 17 & 4 & 0,043911 & 0,0042620 & 0,018461538 & OKE \\
\hline Lantai 16 & 5 & 0,039649 & 0,0020960 & 0,023076923 & OKE \\
\hline Lantai 15 & 5 & 0,037553 & 0,0027730 & 0,023076923 & OKE \\
\hline Lantai 14 & 4 & 0,03478 & 0,0026090 & 0,018461538 & OKE \\
\hline Lantai 13 & 4 & 0,032171 & 0,0028000 & 0,018461538 & OKE \\
\hline Lantai 12 & 4 & 0,029371 & 0,0048750 & 0,018461538 & OKE \\
\hline Lantai 11 & 4 & 0,24496 & 0,0028870 & 0,018461538 & OKE \\
\hline Lantai 10 & 4 & 0,021609 & 0,0012620 & 0,018461538 & OKE \\
\hline Lantai 9 & 4 & 0,020347 & 0,0024380 & 0,018461538 & OKE \\
\hline Lantai 8 & 4 & 0,017909 & 0,0025190 & 0,018461538 & OKE \\
\hline Lantai 7 & 5 & 0,01539 & 0,0035770 & 0,023076923 & OKE \\
\hline Lantai 6 & 5 & 0,01181 & 0,0028440 & 0,023076923 & OKE \\
\hline Lantai 5 & 4 & 0,008969 & 0,00143350 & 0,018461538 & OKE \\
\hline Lantai 4 & 4 & 0,007534 & 0,0017310 & 0,018461538 & OKE \\
\hline Lantai 3 & 4 & 0,005803 & 0,0016540 & 0,018461538 & OKE \\
\hline Lantai 2 & 4 & 0,004149 & 0,0024000 & 0,023076923 & OKE \\
\hline Lantai 1 & 4 & 0,001749 & 0,0017490 & 0,018461538 & OKE \\
\hline TOTAL & 88,05 & & & & \\
\hline
\end{tabular}




\section{Analisis Batas Ultimit Struktur Gedung}

Untuk memenuhi persyaratan kinerja batas ultimitgedung, dalam segala hal simpangan antar tingkat yang dihitung dari simpangan struktur $(\Delta \mathrm{s}$ $\mathrm{x} \zeta$ ) tidak boleh melampaui 0,02 kali tinggi tingkat yang bersangkutan.

Faktor reduksi $(\mathrm{R}) \quad=6,5$

Faktor keutamaan $(\mathrm{I}) \quad=1,4$

Mencari faktor skala :

Faktor skala $\quad=\frac{0,8 \times V 1}{V t} \geq 1$

$$
\begin{aligned}
\text { Fsx } & =\frac{0,8 \times V 1}{V t} \geq 1 \\
& =\frac{0,8 \times 2518987,194}{1810164,57} \geq 1 \\
& =1,113263285 \geq 1
\end{aligned}
$$

Diambil 1,113263285

$$
\begin{aligned}
\text { Fsy } & =\frac{0,8 \times V 1}{V t} \leq 1 \\
& =\frac{0,8 \times 2518987,194}{678632,93} \leq 1 \\
& =2,969484188 \geq 1
\end{aligned}
$$

Diambil 2,969484188
Untuk gedung tidak beraturan :

$$
\begin{aligned}
& \zeta \quad=\frac{0,7 x R}{F S} \\
& \zeta \mathrm{x}=\frac{0,7 x R}{F s x} \quad \zeta \mathrm{y}=\frac{0,7 x R}{F s y} \\
& =\frac{0,7 \times 6,5}{1,113}=\frac{0,7 \times 6,5}{2,969} \\
& =4,088 \quad=1,532
\end{aligned}
$$

\section{Kinerja Batas Ultimit Arah X}

$\Delta$ s lantai Atap - lantai mesin $=0,102204-$ $0,095325=0,006879$

$\zeta \times \Delta \mathrm{s} \quad<0,02 \times \mathrm{h}$

$4,088 \times 0,006879<0,02 \times 2$

$0,0281 \mathrm{~m}<0,04 \mathrm{~m}$ (Memenuhi Syarat)

Untuk perhitungan kinerja batas ultimit arah $\mathrm{X}$ selanjutnya ditampilkan pada tabel 5 .

\section{Kinerja Batas Ultimit Arah Y}

$\Delta$ s lantai Atap - lantai mesin $=0,065865-$ 0,062587 $=0,003278$

$\zeta \mathrm{x} \Delta \mathrm{s}$ $<0,02 \times \mathrm{h}$

$1,532 \times 0,003278<0,02 \times 2$

$0,0050 \mathrm{~m}$

$<0,4 \mathrm{~m}$ (Memenuhi

Syarat)

Untuk perhitungan kinerja batas ultimit arah $\mathrm{Y}$ selanjutnya ditampilkan pada tabel 6 .

Tabel 5 Kinerja Batas Ultimit Struktur Gedung Arah X

\begin{tabular}{|l|c|c|c|c|c|}
\hline \multirow{2}{*}{ Lantai } & \multirow{2}{*}{ Tinggi } & \multicolumn{4}{|c|}{ Kinerja Batas Ultimate Arah X } \\
\cline { 3 - 6 } & & $\Delta \mathbf{s}(\mathbf{m})$ & $\begin{array}{c}\zeta \mathbf{~} \mathbf{\Delta} \text { s antar } \\
\text { lantai }(\mathbf{m})\end{array}$ & Syarat & \multirow{2}{*}{ Ket } \\
\hline Lantai Atap & 2 & 0,101489 & 0,0289 & 0,040 & OKE \\
\hline Lantai Mesin & 5,05 & 0,094418 & 0,0378 & 0,101 & OKE \\
\hline Lantai 19 & 4 & 0,085165 & 0,0304 & 0,80 & OKE \\
\hline Lantai 18 & 4 & 0,077727 & 0,0284 & 0,80 & OKE \\
\hline Lantai 17 & 4 & 0,070767 & 0,0261 & 0,80 & OKE \\
\hline Lantai 16 & 5 & 0,064360 & 0,0243 & 0,100 & OKE \\
\hline Lantai 15 & 5 & 0,058397 & 0,0234 & 0,100 & OKE \\
\hline Lantai 14 & 4 & 0,052667 & 0,0235 & 0,080 & OKE \\
\hline Lantai 13 & 4 & 0,046907 & 0,0227 & 0,080 & OKE \\
\hline Lantai 12 & 4 & 0,041351 & 0,0215 & 0,080 & OKE \\
\hline Lantai 11 & 4 & 0,036074 & 0,0207 & 0,080 & OKE \\
\hline Lantai 10 & 4 & 0,030988 & 0,0206 & 0,080 & OKE \\
\hline Lantai 9 & 4 & 0,025924 & 0,0191 & 0,080 & OKE \\
\hline Lantai 8 & 4 & 0,021246 & 0,0183 & 0,080 & OKE \\
\hline Lantai 7 & 5 & 0,016763 & 0,0185 & 0,100 & OKE \\
\hline Lantai 6 & 5 & 0,012218 & 0,0150 & 0,100 & OKE \\
\hline Lantai 5 & 4 & 0,008534 & 0,0115 & 0,080 & OKE \\
\hline Lantai 4 & 4 & 0,005696 & 0,0083 & 0,080 & OKE \\
\hline Lantai 3 & 4 & 0,003656 & 0,0075 & 0,080 & OKE \\
\hline Lantai 2 & 4 & 0,001821 & 0,0045 & 0,100 & OKE \\
\hline Lantai 1 & 4 & 0,00072 & 0,00294 & 0,080 & OKE \\
\hline TOTAL & 88,05 & - & - & -- & - \\
\hline
\end{tabular}


Tabel 6 Kinerja Batas Ultimit Struktur Gedung Arah Y

\begin{tabular}{|c|c|c|c|c|c|}
\hline \multirow[b]{2}{*}{ Lantai } & \multirow[b]{2}{*}{ Tinggi } & \multicolumn{4}{|c|}{ Kinerja Batas Ultimate Arah Y } \\
\hline & & $\Delta \mathbf{s}(\mathbf{m})$ & $\zeta \times \underset{(\mathrm{m})}{\Delta \mathrm{s} \text { antar lantai }}$ & Syarat & Ket \\
\hline Lantai Atap & 2 & 0,065865 & 0,0050227 & 0,040 & OKE \\
\hline Lantai Mesin & 5,05 & 0,062587 & 0,0123944 & 0,101 & OKE \\
\hline Lantai 19 & 4 & 0,054498 & 0,0081930 & 0,80 & OKE \\
\hline Lantai 18 & 4 & 0,049151 & 0,0080290 & 0,80 & OKE \\
\hline Lantai 17 & 4 & 0,043911 & 0,0065305 & 0,80 & OKE \\
\hline Lantai 16 & 5 & 0,039649 & 0,0032116 & 0,100 & OKE \\
\hline Lantai 15 & 5 & 0,037553 & 0,0042489 & 0,100 & OKE \\
\hline Lantai 14 & 4 & 0,03478 & 0,0039976 & 0,080 & OKE \\
\hline Lantai 13 & 4 & 0,032171 & 0,0042903 & 0,080 & OKE \\
\hline Lantai 12 & 4 & 0,029371 & 0,0074697 & 0,080 & OKE \\
\hline Lantai 11 & 4 & 0,24496 & 0,0044236 & 0,080 & OKE \\
\hline Lantai 10 & 4 & 0,021609 & 0,0019337 & 0,080 & OKE \\
\hline Lantai 9 & 4 & 0,020347 & 0,0037356 & 0,080 & OKE \\
\hline Lantai 8 & 4 & 0,017909 & 0,0038597 & 0,080 & OKE \\
\hline Lantai 7 & 5 & 0,01539 & 0,0054809 & 0,100 & OKE \\
\hline Lantai 6 & 5 & 0,01181 & 0,0043577 & 0,100 & OKE \\
\hline Lantai 5 & 4 & 0,008969 & 0,0021988 & 0,080 & OKE \\
\hline Lantai 4 & 4 & 0,007534 & 0,0026523 & 0,080 & OKE \\
\hline Lantai 3 & 4 & 0,005803 & 0,0025343 & 0,080 & OKE \\
\hline Lantai 2 & 4 & 0,004149 & 0,0036774 & 0,100 & OKE \\
\hline Lantai 1 & 4 & 0,001749 & 0,0026799 & 0,080 & OKE \\
\hline TOTAL & 88,05 & - & - & -- & - \\
\hline
\end{tabular}

\section{Analisis Pushover}

Analisis statik nonlinier merupakan prosedur analisa untuk mengetahui perilaku keruntuhan suatu bangunan terhadap gempa, dikenal pula sebagai analisa Pushover atau analisa beban dorong statik.

Analisis dilakukan dengan memberikan beban lateral statik pada struktur, yang kemudian secara bertahap ditingkatkan dengan faktor pengali sampai satu target perpindahan lateral dari suatu titik acuan tercapai. Biasanya titik tersebut adalah titik pada atap, atau lebih tepat lagi adalah pusat massa atap.

Analisis pushover menghasilkan kurva pushover, kurva yang menggambarkan hubungan antara gaya geser dasar (V) versus perpindahan titik acuan pada atap (D). Pada proses pushover, struktur didorong sampai mengalami leleh disatu atau lebih lokasi di struktur tersebut. Kurva kapasitas akan memperlihatkan suatu kondisi linier sebelum mencapai kondisi leleh dan selanjutnya berperilaku nonlinier. Kurva pushover dipengaruhi oleh pola distribusi gaya lateral yang digunakan sebagai beban dorong.Dari proses iterasi, didapatkan kurva kapasitas yang merupakan hubungan antara perpindahan titik acuan pada atap (D) dengan gaya geser dasar (V).

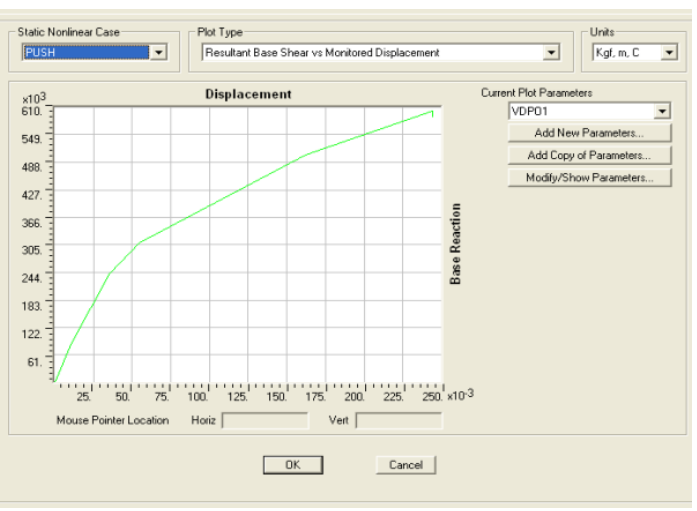

Gambar 6 Kurva Kapasitas 
Jurnal Media Komunikasi Dunia Ilmu Sipil (MoDuluS)

Volume 1, No 1, Juni 2019

Sumber : Gambar hasil run simulasi 3D pada program SAP 2000.

Tabel 7 Pushover Results - Force Displacement

\begin{tabular}{cccccccccccc}
\hline Step & Displacement & BaseForce & AtoB & BtolO & IOtoLS & LStoCP & CPtoC & CtoD & DtoE & BeyondE & Total \\
\hline \multicolumn{1}{c}{$\mathrm{m}$} & Kgf & & & & & & & & & \\
\hline 0 & 0,000000 & 0,000 & 15532 & 0 & 0 & 0 & 0 & 0 & 0 & 0 & 15532 \\
1 & 0,0008107 & 6907,44 & 15529 & 3 & 0 & 0 & 0 & 0 & 0 & 0 & 15532 \\
2 & 0,002844 & 1730423,99 & 14663 & 869 & 0 & 0 & 0 & 0 & 0 & 0 & 15532 \\
3 & 0,011070 & 3959238,08 & 12762 & 2767 & 3 & 0 & 0 & 0 & 0 & 0 & 15532 \\
4 & 0,012759 & 4746691,61 & 12116 & 3370 & 46 & 0 & 0 & 0 & 0 & 0 & 15532 \\
5 & 0,014196 & 6097528,12 & 11001 & 3912 & 601 & 16 & 0 & 2 & 0 & 0 & 15532 \\
6 & 0,014385 & 6405107,27 & 10810 & 3830 & 849 & 39 & 0 & 4 & 0 & 0 & 1552 \\
7 & 0,014606 & 689701,76 & 10497 & 3757 & 1190 & 70 & 0 & 18 & 0 & 0 & 15532 \\
8 & 0,014607 & 6935416,98 & 10477 & 3742 & 1224 & 69 & 0 & 0 & 0 & 0 & 15532 \\
9 & 0,014603 & 7003963,21 & 10441 & 3733 & 1258 & 76 & 0 & 24 & 0 & 0 & 15532 \\
\hline
\end{tabular}

Kurva pada Gambar 6 menunjukan hubungan antara gaya geser dasar terhadap perpindahan yang terjadi akibat beban gempa pada struktur bangunan. Grafik menunjukkan pada saat perpindahan mencapai $0.011070 \mathrm{~m}$ yang terjadi pada step 3, kondisi struktur masih bersifat elastis kemudian berperilaku in-elastis sampai perpindahan mencapai $0.14196 \mathrm{~m}$ pada step 5 . Selanjutnya struktur mulai mengalami keruntuhan dengan ditandai penurunan kurva dengan tajam.

\section{Metode Respons Spectrum}

Performance point pada kurva kapasitas dan kurva respon spektrum.

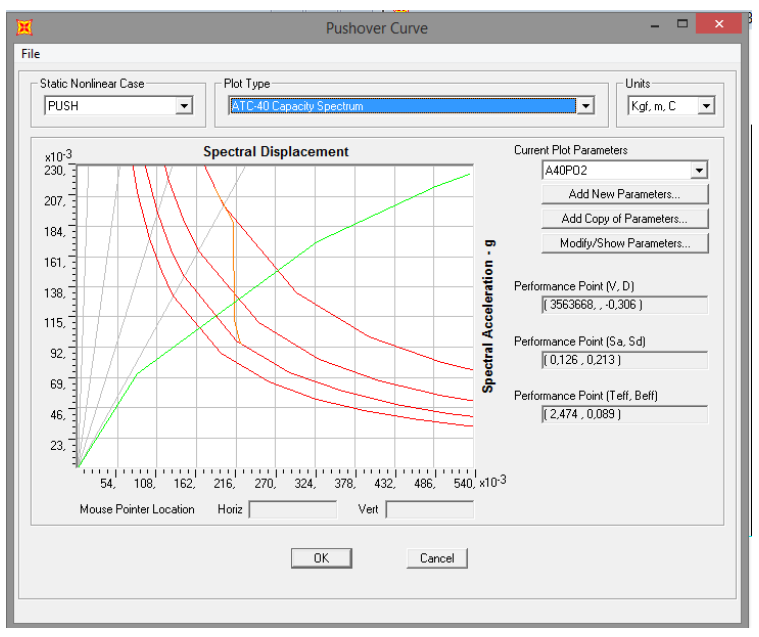

Gambar 7 Kurva Kapasitas Spektrum ATC 40

Sumber : Gambar hasil run simulasi 3D pada program SAP 2000.

Nilai Performance Point :

$\mathrm{V}=3563,668$ ton.

$\mathrm{D}_{\mathrm{t}} \quad=0,306 \mathrm{~m}$

$\mathrm{S}_{\mathrm{a}} \quad=0,126 \mathrm{~g}$
$\mathrm{S}_{\mathrm{d}} \quad=0,213 \mathrm{~m}$

$\mathrm{T}_{\mathrm{eff}} \quad=2,474$ detik

$\beta_{\text {eff }}=0,089$

Displacement Limit menurut SNI 03-17262002 ditentukan $=2 \% \mathrm{H}=0,02 \times 88,05=$ $1,761 \mathrm{~m}>\mathrm{D}_{\mathrm{t}}=0,306 \mathrm{~m}$ maka kinerja displacement gedung baik. Diperoleh nilai gaya geser dasar efektif pada keadaan linier lebih besar dari nilai gaya geser dasar rencana ( $\mathrm{V}=$ $3563,668 \mathrm{t}>$ Vrencana 2648,7532 t ).

Kinerja gedung menurut ATC-40 Tabel 11-12.

- Maksimal Drift $=\frac{\mathrm{Dt}}{\mathrm{H}}=\frac{0,306}{88,05}=0,00347$

Sehingga level kinerja gedung adalah Immediate Occupancy.

- Maksimal In-elastic Drift $==\frac{\mathrm{Dt}-\mathrm{D} 1}{\mathrm{H}}=$ $\frac{0,306-0.011070}{88,05}=0,00221$

Level kinerja gedung Nonlinear adalah Immediate Occupancy.

Maka kinerja gedung saat mencapai gaya geser dasar sebesar $\mathrm{V}=3563,668$ ton masuk pada level Immediate Occupancy yakni ada kerusakan yang pada struktur dimana kekuatan dan kekauannya hampir sama dengan kondisi sebelum gempa dan gedung dapat digunakan kembali.

Perhitungan Performnce Point Menurut ATC-40 Yang Dalam Format ADRS

Faktor $\alpha$ dan MPF

Tabel 8 Faktor $\alpha$ dan MPF

\begin{tabular}{|c|c|c|c|c|c|c|}
\hline Lantai & $\mathrm{W}$ & $\mathrm{m}$ & $\phi$ & $\phi^{2}$ & $\begin{array}{c}\mathrm{m} \mathrm{x} \\
\phi\end{array}$ & $\begin{array}{c}\mathrm{m} \mathrm{x} \\
\phi^{2}\end{array}$ \\
\hline
\end{tabular}




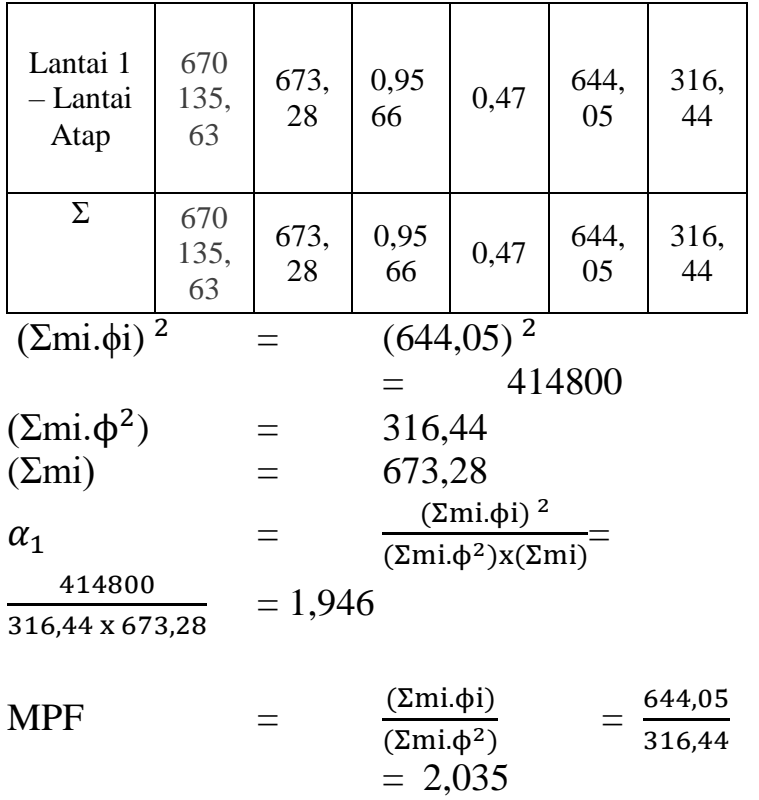

\section{Kurva Kapasitas (Capacity Spectrum)}

$\begin{aligned} \frac{\mathrm{Sa}}{\mathrm{g}} & =\frac{V / W}{\alpha_{1}} \\ & =\frac{26,487532 / 6701,3563}{0,557} \\ & =0,0070\end{aligned}$

$$
\begin{array}{rlr}
\text { Sd } & =\frac{X_{\text {roof }}}{M P F \times \phi_{\text {roof }}} \\
& =\frac{56,5}{2,035 \times 0.456} \\
& =60.8862
\end{array}
$$

\section{Demand Spectrum}

$$
\begin{array}{ll}
a_{y} & =0,27 \mathrm{~g} \\
a_{p i} & =0,33 \mathrm{~g}(\mathrm{Sa} / \mathrm{g}) \\
d_{y} & =2,1 \mathrm{inc} \\
d_{p i} & =3,4 \mathrm{inc}(\mathrm{Sd})
\end{array}
$$

Penyelesaian :

$$
\begin{aligned}
\beta o & =\frac{63,7\left(a_{\mathrm{y}} \mathrm{d}_{\mathrm{pi}}-\mathrm{d}_{\mathrm{y}} \mathrm{a}_{\mathrm{pi}}\right)}{a_{p i} d_{p i}} \\
& =\frac{63,7(0,27 \times 3,4-2,1 \times 0,33)}{0,33 \times 3,4}=12,8 \%
\end{aligned}
$$

Nilai $\beta$ o sebesar $12.8 \%$ pada tipe bangunan A maka nilai damping modification factor $\kappa$ diambil sebesar 1.0.

$$
\begin{aligned}
\beta_{\mathrm{eff}} & =\frac{63,7\left(\mathrm{a}_{\mathrm{y}} \mathrm{d}_{\mathrm{pi}}-\mathrm{d}_{\mathrm{y}} \mathrm{a}_{\mathrm{pi}}\right)}{a_{p i} d_{p i}}+5 \\
& =\frac{63,7(0,27 \times 3,4-2,1 \times 0,33)}{0,33 \times 3,4}+5=17,8 \% \\
\mathrm{SR}_{\mathrm{A}} & =\frac{3,21-0,68 \operatorname{In} \beta_{\mathrm{eff}}}{2,12} \\
& =\frac{3.21-0.68 \operatorname{In} 17.8}{2.12}=0.59 \\
\mathrm{SR}_{\mathrm{V}} & =\frac{2.31-0.41 \mathrm{In} \beta_{\mathrm{eff}}}{1.65}
\end{aligned}
$$

$$
\begin{aligned}
& =\frac{2.31-0.41 \text { In } 17.8}{1.65}=0.68 \\
& =2.5 \mathrm{SR}_{\mathrm{A}} \mathrm{C}_{\mathrm{A}} \\
\mathrm{S}_{\mathrm{a}} & =2.5 \times 0.59 \mathrm{x} 0.40 \\
& =0.59 \mathrm{~g} \\
\mathrm{~T}_{\mathrm{S}} \quad & =\mathrm{SR}_{\mathrm{V}} \mathrm{C}_{\mathrm{V}} /\left(2.5 \mathrm{SR}_{\mathrm{A}} \mathrm{C}_{\mathrm{A}}\right) \\
& =0.68 \times 0.40 /(2.5 \times 0.59 \times 0.40) \\
& =0.46 \text { seconds } \\
\mathrm{S}_{\mathrm{d}} \mathrm{atT}_{\mathrm{S}} & =\mathrm{S}_{\mathrm{a}}(\mathrm{T} / 2 \pi)^{2} \\
& =0.59 \times 386.4(0.46 / 2 \pi)^{2} \\
& =2.5 \mathrm{inc}
\end{aligned}
$$

\section{Performance Level}

Koordinat performance point

$$
\begin{aligned}
\mathrm{Sd} & =\frac{X_{\text {roof }}}{M P F \times \phi_{\text {roof }}} \\
\mathrm{X}_{\text {roof }} & =\mathrm{Sd} \times \text { MPF } \times \phi_{\text {roof }} \\
& =3,4 \times 2,035 \times 0.456 \\
& =3.155 \\
\frac{\mathrm{X}_{\text {roof }}}{\mathrm{H}} & =\frac{3,155}{88,05} \\
& =0,03583
\end{aligned}
$$

Skema Distribusi Sendi Plastis

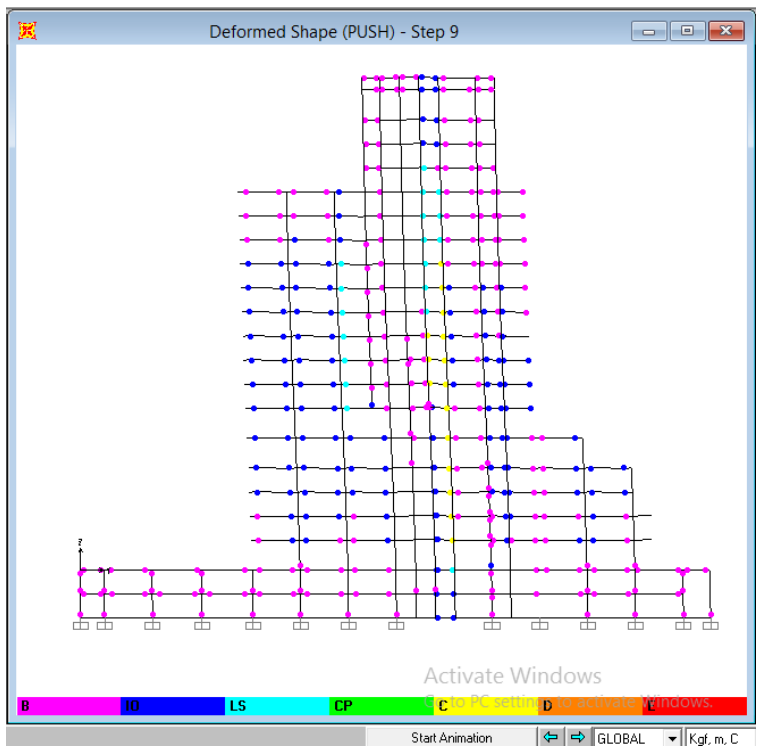

Gambar 8 Gambar hasil run simulasi Sumber : Gambar hasil run simulasi 3D pada program SAP 2000.

Tahap sepuluh, step 9 nilai displacement 0,544 $\mathrm{m}$. Program berhenti melakukan iterasi. Sendi plastis muncul hampir diseluruh elemen balok dan kolom dengan sifat in-elastis. Pada tahap ini $\mathrm{D}=0,014603 \mathrm{~m}$ dan $\mathrm{V}=7003963,21 \mathrm{~kg}$.

\section{KESIMPULAN}


Hasil penelitian menunjukkan bahwa tingkat kinerja struktur bangunan RS. Indriyati Solo Baru berada pada level Immediate Occupancy (IO) dimana pada level ini tidak terjadi kerusakan struktur dan dapat segera untuk digunakan kembali sesuai fungsinya. Analisis struktur berbasis kinerja seperti yang terdapat pada code ATC -40 .

Pada arah X-Z menunjukkan bahwa analisis berhenti pada step 9 , dengan target perpindahan $\delta \mathrm{T}=0,544 \mathrm{~m}$ terlihat pada step 5 (gambar 4.23) dimana perpindahan mencapai $0,477 \mathrm{~m}>\delta \mathrm{T}$, Sebagian sendi plastis elemen balok dan kolom mencapai tahap leleh pertama dengan perilaku nonlinear pada level Immediate Occupancy (IO). Pada kondisi tersebut, terdapat 15532 sendi plastis ditingkat Origin Point (A), 1258 sendi plastis di tingkat Immediate Occupancy (IO), 76 sendi plastis ditingkat Life safety $(L S)$, dan 49 sendi plastis ditingkat Collapse Prevention $(C P)$ yang artinya mengalami kerusakan struktural yang cukup berat, tetapi belum runtuh. Sendi plastis muncul hampir diseluruh elemen balok dan kolom dengan sifat in-elastis. Pada level ini bangunan menimbulkan bahaya yang signifikan. Tetapi hal ini sesuai dengan konsep "kolom kuat - balok lemah" (strong column - weak beam).

\section{DAFTAR PUSTAKA}

ATC-40. 1996. Seismic Evaluation and Retrofit of Concrete Buildings, Volume I. California. Seismic Safety Commission State of California.

Dewobroto, W. 2006. Evaluasi Kinerja Bangunan Baja Tahan Gempa dengan SAP2000. Vol 3, No. 1. Universitas Pelita Harapan.

Pranata, Y.A. 2006. Evaluasi Kinerja Beton Bertulang Tahan Gempa dengan Pushover Analysis ( sesuai ATC-40, FEMA 356 dan FEMA 440 ).

SNI 03-1726-2002, Standar Perencanaan Ketahanan Gempa untuk Struktur Bangunan Gedung.

SNI 03-1727-1989, Pedoman Perencanaan Pembebanan untuk Rumah dan Gedung.

SNI 03-2847-2002, Tata Cara Perhitungan Beton untuk Bangunan Gedung. 